\title{
EXPLORING EFL TEACHERS' UNDERSTANDING AND BELIEFS IN INTERCULTURAL COMMUNICATIVE COMPETENCE IN INDONESIAN CONTEXT
}

\author{
Nisa Hasanah \\ Department of English Education, School of Postgraduates, \\ Indonesia University of Education, Bandung, Indonesia \\ Email: nisahasanah17@upi.edu \\ Wawan Gunawan \\ Department of English Education, School of Postgraduates, \\ Indonesia University of Education, Bandung, Indonesia \\ Email: aawagun@gmail.com
}

\begin{abstract}
APA Citation: Hasanah, N., \& Gunawan, W. (2020). Exploring EFL teachers' understanding and beliefs in intercultural communicative competence in Indonesian context. Indonesian EFL Journal, 6(2), 121-126. doi: 10.25134/ieflj.v6i2.3380.
\end{abstract}

Received: 09-02-2020

Accepted: 01-03-2020

Published: 01-07-2020

\begin{abstract}
As the result of globalization, the English language teaching goals in many countries have shifted from communicative competence to intercultural communicative competence (ICC). However, among the small number of studies on ICC in Indonesia, most of them focus on ICC in the tertiary level which shows there is a gap of work in the secondary level of education. Thus, this article attempts to seek the truth about senior high school teachers' understanding and beliefs as well as revealing their attempts in promoting ICC in the classroom. The case study was employed with two novice teachers as participants through interview and document analysis. The finding shows some interesting facts that both teachers viewed concept of ICC similarly as cross-cultural understanding in a way both to overcome misunderstanding and culture shock. Both teachers believed that language is culture bound, yet, only a very small trace of cultural aspects were shown in the documents; and as they viewed culture as dynamic, yet, the content being taught mainly covered static domain of culture.
\end{abstract}

Keywords: Byram's five savoirs; culture education; intercultural communicative competence.

\section{INTRODUCTION}

Responding to the world demands, English language teaching goals in many countries have shifted to intercultural communicative competence henceforth known as ICC (Abdullah \& Lulita 2018). There are myriad of studies addressing the issue of ICC in English language teaching all over the world. However, in Indonesia, among the very limited number of works in ICC, mainly the studies focus on tertiary level of education such as in Widodo \& Kusumaningputri (2018), Abdullah \& Lulita (2018), and Tedjakusuma (2013). Hence, it indicates that there is an absent of work in ICC especially primary and secondary level of education. Therefore, this study attempts to gain insight and explores EFL secondary teachers' understanding and beliefs towards the concept of ICC in Indonesian context.

Grounded from Byram's theory (1997), intercultural communicative competence in the context of English for foreign language classroom is the students' potentiality to scrutinize cultural knowledge/perspectives, practice/behaviors, artifacts of native speakers and non-native speakers' group, and how to deal with them in a non-judgmental way. In this way, the ICC takes up intercultural knowledge, attitudes, and skills that can assist students in directing, examining, associating, interpreting, and evaluating cultural matters represented through social practices and artifacts from various perspectives (Kusumaningputri \& Widodo, 2018). In similar stance, ICC is also conceptualized as the communicative ability to understand and accommodate the communication between/among people of different cultures in a way that it bridges them both linguistically and culturally with the capacity of relating to others effectively (Mirzaei \& Forouzandeh, 2013; Deardoff, 2006).

Byram (1997) described intercultural competence in terms of several savoirs. There are five savoirs, which also known as intercultural competence model in which he identified knowledge, skills, and attitudesessential for successful communication across cultural 


\section{Nisa Hasanah \& Wawan Gunawan}

Exploring EFL teachers' understanding and beliefs in intercultural communicative competence in Indonesian context

boundaries. Those savoirs are savoir (expert knowledge), savoir etre (intercultural attitudes and beliefs), avoir-apprendre/faire (intercultural discovery and interaction), savoir-comprendre (skills of interpreting and relating), and savoir s'engager (critical cultural awareness).

Within the context of ICC in the foreign language learning, the learning goals is not at the level of native speaker of the target language, instead, the students should follow the norm of 'intercultural speaker' (Byram, 1997; Kramsch, 1993; Risager, 1998). In other words, ICC pushes students to go beyond their own culture and the target language culture and open them to the various cultures to prepare them to live and to communicate in global world (Kiss, 2017).

\section{METHOD}

This study aims to answer to the following research questions:

1) What do EFL teachers understand about ICC?

2) What are teachers' beliefs about the concept of intercultural communicative competences in the context of English for foreign language in Indonesia?

3) What are the teachers attempts to promote intercultural communicative competences in their classroom teaching practice?

This study employs the qualitative case study since the data is in form of words, phrases, and sentences. It is also because the qualitative case study is descriptive in nature and related to human behavior of how people behave, feel, think (Gillham, 2000), in this case are related to teachers' cognition.

The participants of this study were EFL teachers of senior high school. In order to gather the data, a semi-structured interview and document analysis are conducted. Prior to data collection, the teachers were handed the consent form to verify their willingness to participate in the study.

The data of interview were analyzed based on the qualitative data analysis of interview model (Merriam, 2009; Cohen, Manion, Morrison 2001; Gillham, 2000). Upon the completion of the data collection, the interview data from the participants were transcribed and coded based on several themes. All the coded data were then read repeatedly and the data relevant were formulated to answers the three proposed research questions. As for the document analysis, the data were used to complement and support the findings in the interview and to prove whether the teachers' sayings are in line or contradicted with the evidence from formal document.

\section{RESULTS AND DISCUSSION}

The findings and discussion are presented consecutively and organized based on its relevance with the research question. Therefore, they will be broken down into three parts following three research questions.

What do EFL teachers understand about ICC? In order to collect teachers' understanding about ICC, the teachers were asked several questions. In addition, to engage teachers to the topic, the interview questions were preceded by several questions about culture content in English language education. Those questions including the teachers' view of the way culture and language related, the teachers' view about the importance of culture in English language education, and the way teachers view ICC in English curriculum in Indonesia. In response to these questions, the teachers nearly had similar responses. They both knew that culture is related to language teaching in a way that language is a product of culture and that the foreign status of English in Indonesia makes it necessary for students to know how to use the language in cultural context. They also contended that culture is important in language teaching to prepare their students for future needs such as studying abroad, travelling, or even working in foreign company. The teachers were aware that cultural content was there in government's curriculum, although one of them said it was there in textbook while she did not really aware of it in curriculum document.

Being asked about ICC, surprisingly both teachers had one voice. Both teachers defined ICC exactly the same as "Cross Cultural Understanding" or CCU. CCU was what came to their mind since it was one of the culture-related subjects being taught in English teacher training program even though they were graduated from different college. One of the teachers said that:

“... ICC may be still unfamiliar to me, however when I was studying in the college, I have learned about cross cultural understanding which may be similar to what my lecturer taught me so that culture shock and misunderstanding can be avoided.

.... cross cultural is across culture, it is something about introducing and understanding cross culture..."

When the teachers said ICC was CCU, it was partially true because those two words of intercultural and cross cultural are sometimes used interchangeably as they both address the 
same issues such as overcoming misunderstanding in communication as well as overcoming cultural shock. However, both terms are not similar in nature as they were delivered from different perspectives. Lustig and Coester (1993) had identified the distinction between two terms. Intercultural competence, they said, is interpersonal communication across culture. Further, they stated that it is "a symbolic, interpretative, transactional, contextual process" which indicated the engagement people with culturally different background. Meanwhile, cross culture was defined as the study of ideas or concepts within many cultures for the purpose of comparing one culture to another and comparing interaction among people with similar cultural background to those from another culture (Lustig \& Coester, 1993).

As for the teachers, from their answers, both teachers did not seem to familiar with and know about ICC. However, they did know something about the topic, and they found it necessary in language teaching. These findings are approved and harmonious with what Bektas-Centikaya and Celik (2013) found in Turkish EFL preservice teacher that they did not have adequate knowledge about ICC as it was not included in their teaching preparation program. It is also in phase with finding of Atay, Kurt, Camlibel, Ersin, \& Kaslioglu (2009) from 503 teacher participants which stated that teachers in Turkey are aware of the importance of culture in language teaching even though not many of them directly integrate culture into their teaching practice. Thus, in both Turkey and Indonesia as non-English speaking country, ICC is seemed rather unfamiliar in concept yet important in meaning, at least to these two teachers.

\section{What are teachers' beliefs about teaching intercultural communicative competences in the context of English for foreign language in Indonesia?}

This question aims to dig deeper into the teachers' beliefs about ICC and developing students' ICC. These teachers' beliefs are important because belief is operated as filters and affect the way teacher view his/her new teaching situation so that teacher can shape teaching goals covering the needs of new situation (Pajares, 1992). In this part, the questions were ranging from the way teachers see culture, what culture to teach, what do teachers emphasize in culture teaching, what are their goals in teaching culture, how do they set their students position and their roles in the classroom, their views about possibilities in putting ICC as language learning goals, and how do ICC is reflected in their beliefs and their document such as syllabus, lesson plans, textbook, and teaching materials.

Answering to the question about the view of cultures, the teachers agreed that culture is dynamic, and that language is the product of culture. Therefore, language and culture are seen inseparable. This statement is in line with Kiss \& Weninger (Kiss \& Weninger, 2013, 2017; Weninger \& Kiss, 2013) which view culture changes over time. From this point of view, it is such disagreement when culture is taught only in form of facts without giving students certain skills to overcome those changing facts.

Regarding the question of what cultural contents they teach, the teachers have different perspectives along with their different reasonings. The first teacher focus on teaching students several cultural facts such as typical foods and habits of people from English speaking country. In addition, cultural difference is also taught in form of comparing West culture and East culture in essence that students should appreciate those differences.

“...for example, about European countries or other country aside from Indonesia, what are their favorite foods, their favorite activities which might be different from Indonesians. "

"...so as teacher we should teach and show students which are Western culture, which are Eastern culture, and which are Indonesian culture ....this is the way to prevent students from being discriminative when confronting differences, we should respect and bear in mind that those are other people's cultures."

The first teacher's domain of teaching culture revolved around cultural knowledge and facts. The teacher saying about teaching culture in form of cultural facts conceptualized as the savoir of Byram (1997), that is the students' knowledge about culture. However, even though the teacher stating about appreciating differences, it cannot be categorized as the next savoir because the activity that the teacher used to illustrate are only about the activities of sharing knowledge and facts such as knowledge inquiry about certain topic of culture through presentation method. Yet, if we compare this statement with Kiss \& Weninger (Kiss \& Weninger, 2013, 2017; Weninger \& Kiss, 2013), this kind of culture teaching is actually not regarded as ICC for it contradicts the dynamic culture trait.

When the first teacher was asked to clarify about her focus of culture teaching, the teacher 


\section{Nisa Hasanah \& Wawan Gunawan}

Exploring EFL teachers' understanding and beliefs in intercultural communicative competence in Indonesian context

reformulated her answer that she focused on British, American, and Australian culture, and later Indonesia. The teacher also contended that language teaching goals was non-other than native speaker's alike and it is the undeniable fact. This statement is contradicted with the ICC's principal in which the goal of ICC is not to accomplish native speaker alike because there have been bias whether in order to communicate with people from other culture one needs the level of native speaker alike in terms of accent and fluency. It is because what is emphasized in ICC is how the communication can bridge people of different culture to communicate effectively and to vanish the barrier between them (Byram, 1997).

Later, in the document, it was found that the teacher' goals of teaching were purely about linguistic competence and National Examination preparation. There was no trace of cultural aspects mentioned in both syllabus and lesson plan. Thus, we can say that the teacher takes culture in English language teaching as something additional and unofficial rather than full awareness of culture importance in language teaching. From here, the inconsistencies in between statements were found where the first teacher's statement was disproved with her earlier statement about the importance of culture in EFL teaching for students.

In setting the students' position and teacher's position in the classroom, both teachers viewed that learning should be student-centered and that they take roles as facilitators. Their views are supported by their illustration of classroom activities where students are mostly assigned to work in group to do some cooperative learning activities such as two stay two stray, etc. This view somehow is one of the characteristics of ICC learning where teacher role is not as the sole source of knowledge. Instead, students should actively engage in learning activities and in knowledge inquiry.

On the other hand, the findings in the second teacher indicate that she has rather different perspective with the first teacher in some parts. She believes that in teaching culture, what should be emphasized is the students' own culture. Because lately, students tend to be more devoted to other culture and tend to have no pride over their identities. The teacher believes that her students are more knowledgeable in other culture because of their exposure through internet and travelling.

\begin{abstract}
"As the technology is getting more and more modern and advanced, sometimes students know more about other cultures, but they forget about their own culture. So, for me, I have to implanted the local culture...so that they will understand that learning English does not always mean the students have to focus on the target language culture, but they have to be aware that they have their own culture and they should not put their own culture aside."
\end{abstract}

She also added that in addition to two cultures being taught, she also teaches the other culture apart from local and target language culture. This way, she tried to engage the students more to the world and directed their focus not only to the target language culture. This is also in harmony with the principal of ICC according to Byram (1997) which states that in ICC, students are not only taught the target language culture, but also culture of their own, and culture other than target language culture. In addition, the second teacher's goals in culture teaching accentuates on moral, local wisdom, how to put oneself appropriately in various culture, and how to become an openminded person when facing differences. Her goals of culture teaching were supported by the syllabus and lesson plan which stated not only linguistic competence as the sole goals but also shaping the students' way of thinking, values, and selfesteem. In shaping the students' way of thinking the goals consist of becoming open minded, learning to see things from different perspectives, and exploring hidden message. In shaping the students' values, the goals consist of learning from other culture and appreciating creative solution. Finally, in shaping the students' selfesteem, the learning goals are being able to be diplomatic and being proud of who they are. These goals stated in the syllabus and lesson plan become the documented prove that she integrated ICC into her teaching practice.

In the possibility of making ICC as the fundamental aim of language teaching, both teachers were agreed that it is possible with certain conditions. The first teacher opined that it is possible if the students' linguistic competencies are adequate. While the second teacher, contended that it is possible if given additional time for teaching English and possible if the students' linguistic competencies are adequate. She also added that cultural topic is interesting because it gives her more to discuss with students in the classroom. 


\section{What are the teachers attempts to promote intercultural communicative competences in their classroom teaching practice?}

The last part of the findings and discussion is about to answer the last research question. In this part, the findings were not obtained through observation even though the question is implied to the teachers' practice. By incorporating into teaching means that it is about what teachers said about what they did with cultural content, how do they accommodate cultural learning, what kind of activities to do with cultural content, and how often the culture is being taught.

The first teacher explained one of activity that she had with her students.

"For example, the topic is about the tour guide. I divide students into several groups. Each group will be given a different theme to be explored. For instance, I gave the UK as the topic for the first group, they should gather information regarding the UK....as for the tour guide, the information needed such as local foods in the UK and interesting facts about UK....From there, students should write about the UK, and they should present their group works."

This activity reflects the teacher's firmness with her statement in student-centered learning. However, in ideal ICC stance, learning culture should not stop there on students' discovery, the teacher should also mediate students to make meanings through discussions and relate students' culture with the culture being learned (Norton, 2000)

Being asked how often she involved culture into her teaching, she honestly confessed that she did not do cultural teaching so often. She will discuss culture only if the topic or material is really related to the culture such as tour guide topic, traveling topic, and studying abroad topic. It seems that the teacher still treat culture separately from the language learning. This finding is parallel to Byram's finding in 2013 . He found that even though many teachers aware of culture are inseparable, many of them still treat culture as an extra skill apart from reading, listening, writing, and speaking (Byram, 2013).

As for the second teacher, she explained that her ways of culture teaching are through assigning students in different tasks such as creating video content about culture, writing articles about certain issues regarding the culture, making cultural artworks and scrapbook, and inserting cultural content into four skills activities and other topic discussions.

"Sometimes, I assign students to do speaking task in form of creating video content or vlog. The video content should be about culture, for example describing the historical building and comparing the historical building in Indonesia with other countries.... assign them to write an article about culture. They came up with immigrants in America or gap perspective between parents and children in Indonesia.....I also assign them to make artwork in form of a scrapbook or $3 D$ wall magazine about culture.......sometimes discussing culture in Europe and comparing with Indonesian culture..."

From the transcription, it shows that the second teacher has brought cultural teaching to the next level. She did a variation in her teaching. She has integrated culture in many of her teaching activities. The activities include knowledge inquiry which is the focus of the first savoir, comparing, contrasting, and relating which indicate Savoir-comprendre, criticizing and synthesizing in article writing indicating savoir $s$ 'engager, additionally, in syllabus the value shaping of being open-minded and curious is reflecting the savoir etre. In conclusion, the second teacher teach almost all skills that Byram proposed even though it might only cover a small number of the whole part in each skill. Moreover, by integrating cultural aspect into the teaching of four skills, it means that this teacher, regardless of her inability to explain appropriately what ICC was, she has put ICC into her regular teaching practice.

\section{CONCLUSION}

This study represents the teachers' understanding and beliefs about intercultural communicative competence in English language teaching and teachers' attempts to promote ICC in their teaching practices. Based on the findings, it shows that both teachers have relatively trivial knowledge about the concept of ICC; however, when given the context of culture in language learning both teachers can elaborate further about the concept in their frame of views and show concerns about the importance of ICC in language learning at different level. In addition, teachers have certain beliefs regarding the teaching of intercultural communicative competences which some are in line with the intercultural competences framework and supported by the findings in previous studies while others are on the contrary. Meanwhile, the teachers' attempts in promoting ICC are varied to certain degrees. The inconsistencies are also found in between each teacher's statements, that one and another statement are not approved and supported each other and in between statement and what was 


\section{Nisa Hasanah \& Wawan Gunawan}

Exploring EFL teachers' understanding and beliefs in intercultural communicative competence in Indonesian context

found in the documents. Nevertheless, the teachers cannot be judged for not putting culture discernibly into syllabus or lesson plan; this occurrence may happen due to the teacher's vision is not in line with the school's vision that she cannot put what she thinks into practice or that teachers may not have sufficient time to spare for their main goals are dictated by the National Examination which are not discussed in this study.

\section{ACKNOWLEDGEMENT}

We would like to thank everyone who have involved in this study, particularly the participants of the study, and those who have helped and supported while we are completing this study.

\section{REFERENCES}

Abdullah, F., Lulita. (2018). Social actors in an intercultural communication classroom: A discursive lens of intercultural education. Indonesian Journal of English Language Teaching, 13(1), 31-51.

Atay, D., Kurt, G., Camlibel, Z., Ersin, P., \& Kaslioglu, O. (2009). The role of intercultural competence in foreign language teaching. Inonu University Journal of the Faculty of Education, 10 (3), 123-135.

Bektas-Centinkaya, Y., \& Celik, S. (2013). Perceptions of Turkish EFL candidates on their level of intercultural competence. In H. Arslan \& G. Rata (Eds.), Multicultural education: From theory to practice (345-362). Newcastle: Cambridge Scholar Press.

Byram, M. (2013). Intercultural communicative competence in foreign language education: Question of theory, practice and research. The Language Learning Journal, 41(3), 251-253.

Byram, M. (1997). Teaching and Assessing Intercultural Communicative Competence. Clevedon: Multilingual Matters.

Byram, M. (2006). Language teaching for intercultural citizenship: The European situation. Paper presented at the NZALT conference, University of Auckland.

Cohen, L., Manion, L., \& Morrison, K. (2007). Research methods in education sixth edition. New York: Taylor-Francis.

Deardorff, D. K. (2006). Identification and assessment of intercultural competence as a student outcome of internationalization. Journal of studies in international education, 10(3), 241-266.

Gillham, B. (2000). Case study research methods. New York: Continuum.

Kiss, T. (2017). Developing intercultural communicative competence: An example of the New College English textbook series. Indonesia
Journal of English Language Teaching, 12(1), 7999.

Kiss, T., \& Weninger, C. (2017). Cultural learning in the EFL classroom: The role of visuals. ELT Journal, 71, 186-196. doi: 10.1093/elt/ccw072.

Kiss, T., \& Weninger, C. (2013). Exploring cultural potential in EFL textbooks: Fostering cultural reflexivity in the classroom. Malaysian Journal of ELT Research, 9(1), 19-28.

Kramsch, C. (1993). Context and culture in language teaching. Oxford: Oxford University Press.

Kusumaningputri, R., \& Widodo, H.P. (2018). Promoting Indonesian university students' critical intercultural awareness in tertiary EAL classrooms: The use of digital photographmediated intercultural tasks. System, 72, 49-61.

Lustig, M. W., \& Koester, J. (1993). Intercultural competence: Interpersonal communication across cultures. New York: Harper Collins College Publishers.

Merriam, B. S. (2009). Qualitative research: A guide to design and implementation. San Francisco: Jossey-Bass.

Mirzaei, A., \& Forouzandeh, F. (2013). Relationship between intercultural communicative competence and L2-learning motivation of Iranian EFL learners. Journal of Intercultural Communication Research, 42(3), 300-318.

Norton, B. (2000). Identity and Language Learning: Gender, Ethnicity, and Educational Change. London: Longman.

Reid, E. (2015). Techniques developing intercultural communicative competences in English language lesson. Proceedia, 186, 939-943. doi: 10.1016/j.sbspro.2015.04.01.

Risager, K. (1998). Language teaching and the process of European integration. In M.B.M. Fleming (Ed.), Language learning in intercultural perspective. Approaches through drama and ethnography. Cambridge: Cambridge University Press.

Pajares, M. F. (1992) Teachers' beliefs and education research: cleaning up a messy construct, Review of Educational Research, 63, 307-332.

Tedjakusuma, H. J. H. (2013). Teaching culture to adult Indonesian students in English classrooms: A mutual understanding approach. Magister Scientiae, 34, 194-202.

Thanasoulas, D. (2001). The Importance of Teaching Culture in the Foreign Language Classroom." Radical Pedagogy. Retrieved June 14, 2020 .http://radicalpedagogy.icaap.org/content/issue3_ 3/7thanasoulas.html.

Weninger, C., \& Kiss, T. (2013). Culture in English as a Foreign Language (EFL) textbooks: A semiotic approach. TESOL Quarterly, 47(4), 694-716.

Widodo, H. P., Wood, A., \& Gupta, D. (Eds.). (2017). Asian English language classrooms: Where theory and practice meet. New York: Routledge. 